\author{
CURRENT CONCEPTS: \\ The Melanotropic Peptides
}

\title{
III. REGULATION OF CYCLIC-AMP SYNTHESIS IN AMPHIBIAN MELANOTROPE CELLS THROUGH CATECHOLAMINE AND GABA RECEPTORS
}

B.M. Lidy Verburg-van Kemenade, Bruce G. Jenks, A.J.H.M. Houben

Department of Zoology, Faculty of Science, Catholic University, Toernooiveld, 6525 ED Nijmegen, The Netherlands.

\section{Summary}

Catecholamines and GABA are neurotransmitters involved in the regulation of release of pro-opiomelanocortin (POMC) derived peptides from the neurointermediate lobe of Xenopus Laevis. The present study concerns the relation of these neurotransmitters to the adenylate cyclase system of the melanotrope cell. During in vitro incubation of isolated melanotrope cells it was found that dopamine, adrenaline and LY 171555 induced inhibition of forskolin-stimulated cAMP production and concomitantly inhibited MSH release.

Activation of the GABAb receptors by baclofen also induced inhibition of CAMP production and aMSH secretion. Activation of the GABAa receptors evoked stimualtion of cAMP production, while aMSH release was slightly inhibited, indicating that the GABAr mechanism may prove to be complex. A dual regulation through two subtypes of this receptor might be involved, one stimulating release through the adenylate cyclase system, while the other would inhibit secretion.

The secretory cells of the pars intermedia of the pituitary gland synthesize the bioactive peptide Melanophore-Stimulating Hormone (aMSH). In amphibians, these melanotrope cells are involved in the neuroendocrine reflex regulating pigment dispersion in dermal melanophores (background adaptation). Animals placed on a black background release aMSH which, by stimulating dispersion of black pigment within the melanophores, leads to a darkening of the animals $(1,2)$. Recent studies indicate that hypothalamic regulation of the secretory activity of amphibian melanotropes, which involves stimulatory and inhibitory mechanisms, is exerted through a number of factors, both classical neurotransmitters $(3,4,5$, $6,7)$ and neuropeptides $(8,9,10,11)$. Many of these factors function through a direct action on the melanotrope cell itself (12), indicating that this cell is a major center of neuroendocrine integration. An understanding of the intracellular mechanisms of this integration may help in establishing the physiological significance of the general phenomenon of multiple factors regulating pituitary cell function.

It has been shown that regulation of aMSH release from the pars intermedia of the aquatic toad, Xenopus laevis, involves both a dopaminergic and a GABAergic system. Dopamine induces an inhibition of MSH secretion (13, 14, 15). Studies with isolated melanotrope cells of Xenopus (cell suspensions) have established that this effect is exerted through direct action of the secretagogue on the melanotrope (12). Using specific receptor agonists and antagonists it has been shown that, in Xenopus, dopamine functions through a receptor which has similar but not identical characteristics to the dopamine $D_{2}$ receptor of mammalian melanotropes (16). The pars intermedia of Xenopus zaevis possesses a rich net- 
work of GABAergic nerve terminals, and the neurotransmitter GABA is very potent in inhibiting secretion of MSH from the intermediate lobe of this amphibian (7). Receptor characterization studies show that both GABAa and GABAb receptors are present and that activation of either receptor type leads to an inhibition of MSH secretion (17). GABAa and GABAb receptor agonists inhibit secretion from the isolated Xenopus melanotrope, indicating that the melanotrope itself possesses both GABA receptor-types (12).

Earlier studies have reported the involvement of cyclic-AMP (cAMP) in the release process of the Xenopus MSH cells (6, 14, 18, 19). The purpose of the present investigation was 1) to establish if dopamine inhibits MSH release from the Xenopus melanotrope through an inhibition of the adenylate cyclase system and 2) to determine the effect of specific GABAa and GABAb receptor agonists on the production of cyclic-AMP by these cells. For this purpose isolated melanotropes of Xenopus laevis were used. cAMP levels were measured using a cyclic-AMP protein binding assay, and the secretion of MSH from the melanotropes was monitored by radioimmunoassay.

\section{Materials and Methods}

\section{Animals}

Xenopus laevis were bred and reared in our aquatic facility. Prior to the experiments the animals were kept for at least two weeks on a black background under constant illumination at $22 \mathrm{C}$.

\section{Preparation of cell suspensions}

Preparation of cell suspensions and tests concerning cell viability have been published earlier (12). Neurointermediate lobes were dissected in incubation medium (IM) containing $112 \mathrm{mM} \mathrm{NaCl}, 2 \mathrm{mM} \mathrm{KCl}, 2 \mathrm{mM} \mathrm{CaCl} \mathrm{H}_{2} .2 \mathrm{H}_{2} \mathrm{O}, 2 \mathrm{mg} / \mathrm{ml}$ glucose, $15 \mathrm{mM}$ Hepes $\mathrm{pH} 7.38$. The medium was preaerated with carbogen. The tissue was subsequently transferred to $1.5 \mathrm{ml}$ IM to which was added $3 \mathrm{mg} / \mathrm{ml}$ bovine serum albumin (BSA, Sigma fraction V), $1 \mathrm{mg} / \mathrm{ml}$ collagenase (Sigma) and $1.25 \mathrm{mg} / \mathrm{ml} \mathrm{dis}-$ pase (grade II lyophilisat, Boehringer) and incubated for $1 \mathrm{~h}$ in a shaking waterbath at $22 \mathrm{C}$. After centrifugation $(10 \mathrm{~min}, 200 \mathrm{~g}, 22 \mathrm{C})$ the pellet was carefully suspended in $1.5 \mathrm{ml} \mathrm{Ca-free} \mathrm{medium} \mathrm{to} \mathrm{which} 3 \mathrm{mg} / \mathrm{ml} \mathrm{BSA}$ and $0.4 \mathrm{mg} / \mathrm{ml}$ EDTA were added. The suspension was centrifuged, resuspended in $1.5 \mathrm{ml} \mathrm{Ca-free} \mathrm{medium}$ with $3 \mathrm{mg} / \mathrm{ml}$ BSA and $1.25 \mathrm{mg} / \mathrm{ml}$ dispase and incubated for $30 \mathrm{~min}$ at $22 \mathrm{C}$ with shaking. Tissue fragments were then allowed to settle and the supernatant containing melanotropes in suspension (fraction 1) was saved. The fragments were rinsed and retreated with $\mathrm{Ca}$-free medium containing BSA and dispase, and centrifuged for $3 \mathrm{~min}$ at $200 \mathrm{~g}$ over a nylon filter (pore size $0.15 \mu \mathrm{m}$ ). The collected cell suspension (fraction 2) was combined with fraction 1 and centrifuged (10 $\min 200 \mathrm{~g}$ ). The pellet was rinsed and resuspended in medium containing $3 \mathrm{mg} / \mathrm{ml}$ $\mathrm{BSA}, 0.8 \mathrm{mg} / \mathrm{ml}$ EDTA. Finally it was centrifuged and suspended in incubation medium with $0.3 \mathrm{mg} / \mathrm{ml}$ BSA. All glassware was siliconized.

\section{Superfusion of isolated melanotropes}

Cells were suspended in a small volume of incubation medium and loaded in a 50 $\mu l$ superfusion chamber with a millipore $0.45 \mu \mathrm{m}$ filter (type HA) at the outlet to support a layer of biogel P2 (Biorad). After loading, the chamber was filled with biogel. Medium was pumped with a peristaltic pump at a rate of $1.5 \mathrm{ml} / \mathrm{h}$ and $7.5 \mathrm{~min}$ fractions were collected in $100 \mu 1$ ice-cold $0.1 \mathrm{~N} \mathrm{HCl}$. Fractions were stored at $-20 \mathrm{C}$ before submission to radioimmunoassay. After an equilibration period of approximately $1 \mathrm{~h}$ the effect of cAMP was investigated by giving $15 \mathrm{~min}$ pulses of medium containing $6 \mathrm{mM} \mathrm{8-Br-cAMP} \mathrm{(Sigma).}$

Radioimmunoassay for $\alpha M S H$

The C-terminal directed antiserum was produced and characterized by Vaudry et al (20). This antiserum has equal reactivity to aMSH and des-acetyl-aMSH. Bound 
and unbound MSH were separated by precipitation with polyethyleneglycol (final concentration $7.5 \%$ ). Sensitivity threshold of the assay is $5 \mathrm{pg}$.

Static incubations of melanotrope cells

Cells were washed in IM with $3 \mathrm{mg} / \mathrm{ml} \mathrm{BSA}$ and $10^{-4} \mathrm{M}$ of Isobutylmethyl Xanthine (IBMX, Sigma). After centrifugation these cells were subsequently incubated for $45 \mathrm{~min}$ in $250 \mu \mathrm{l}$ of IM containing $0.3 \mathrm{mg} / \mathrm{ml} \mathrm{BSA}, 2 \mathrm{mg} / \mathrm{ml}$ glucose, $10^{-4} \mathrm{M}$ IBMX, and $30 \mu \mathrm{M}$ of forskolin at $22 \mathrm{C}$. Cells were then centrifuged for $10 \mathrm{~min}$ at $200 \mathrm{~g}$ and $200 \mu \mathrm{l}$ supernatant was taken for radioimmunoassay of aMSH. To the cells 450 $\mu 1$ of $6 \% \mathrm{TCA}$ was added (end concentration of TCA $\pm 5 \%$ ) and the proteins were allowed to precipitate for $15 \mathrm{~min}$ on ice. The mixture was centrifuged at $2000 \mathrm{~g}$ and the supernatant was kept at $-20 \mathrm{C}$ for cAMP binding assay.

To investigate the effect of neurotransmitters on the intracellular cAMP production, experimental incubations were performed in presence of $10^{-5} \mathrm{M}$ dopamine (Sigma), 10-5M dopamine $+30 \mu M$ pertussis toxin (P.H.L. Service, Centre for applied Microbiol. and Research, Salisbury); $5 \times 10^{-7} \mathrm{M}$ LY171555 (Lilly Co.); 10-6M adrenaline; $10^{-5} \mathrm{M}$ baclofen (a kind gift of Ciba Geigy) or $10^{-4} \mathrm{M}$ isoguvacine (Cambridge Research Chemicals).

cAMP binding assay

cAMP binding assay was based on the method according to Kempen et a1. (21). cAMP binding protein, prepared according to Brown et al. (22), was kindly provided by Dr P.H.G.M. Willems. TCA was eliminated from the supernatant by repeated extraction with $5 \mathrm{ml}$ of water-saturated diethylether. Subsequently 2 pmol of [ $3 \mathrm{H}$ ] CAMP ( $48 \mathrm{Ci} / \mathrm{mmol}$ Amersham) was added. The extract was purified over a Dowex-50WX8 column $(3 \mathrm{~cm} \times 0.5 \mathrm{~cm}$ ) which was equilibrated in $0.01 \mathrm{~N} \mathrm{HCl}$ and eluted with destilled water. The cAMP containing fraction was dried overnight under $\mathrm{N}_{2}$ at $30 \mathrm{C} .350 \mu \mathrm{l}$ of cAMP binding protein, dissolved in medium containing $50 \mathrm{mM}$ Tris (pH 7.4), $8 \mathrm{mM}$ theophylline, $5 \mathrm{mM} \mathrm{EDTA,} 1.7 \mathrm{mM} \mathrm{MgSO} .7 \mathrm{H}_{2} 0,0.93 \mathrm{mg} / \mathrm{ml}$ dithiothreitol (D.T.T.), was added to the dry sample which was then left for $1 \mathrm{~h}$ on ice. Of this sample $50 \mu 1$ was taken to measure the recovery of c-AMP for each column. To the remaining $300 \mu 1,1 \mathrm{ml}$ of charcoal $0.01 \mathrm{~g} / \mathrm{ml}$ in $50 \mathrm{mM} \mathrm{Tr}$ is $\mathrm{pH} 7.4,0.2 \mathrm{~g} / \mathrm{ml}$ BSA was added. After mixing and centrifugation ( 5 min at 3000 g) $500 \mathrm{\mu l}$ of the supernatant was added to $4 \mathrm{ml}$ of Scintillator 199 (Packard) and the radioactivity was determined in a liquid scintillation analyzer. For each assay a standard curve was made by adding [3H]cAMP to known amounts of cAMP which were then treated identical to the tissue samples, to subsequently establish recovery and \% binding.

\section{Results}

Effect of 8-Br-cAMP on MSH release

Administration of CAMP during in vitro superfusion of isolated intermediate lobe cells resulted in a significant increase of MSH secretion from these cells to $233 \pm 63 \%(n=4)$ (fig. 1). After $7.5 \mathrm{~min}$ a small increase was visible which only reached a maximum after $30 \mathrm{~min}$.

\section{Measurement of cAMP production}

Preliminary experiments showed that basal levels of cAMP in isolated melanotropes of Xenopus laevis were under the limit of detection of the binding assay. Production of cAMP during a one hour in vitro incubation of 2 pars intermedia equivalents of cells in the presence of IBMX also remained under the detection limit. Stimulation of cAMP synthesis by forskolin resulted in a dose- and timedependent increase of cAMP production and therefore forskolin was used in all subsequent incubations to bring cAMP production within detection limits of the assay. A $45 \mathrm{~min}$ in vitro incubation in $30 \mu \mathrm{M}$ forskolin was selected as the standard incubation protocol. During this period an average of $51.1 \pm 5.3 \mathrm{pmol}$ cAMP/intermediate lobe was measured $(n=29)$. 
Fig. 1. Stimulation of aMSH secretion by 8-Br-cAMP during in vitro superfusion of intermediate lobe cells of Xenopus Zaevis. CAMP ( $6 \mathrm{mM})$ was administered during $15 \mathrm{~min}$ of the superfusion period as indicated in the figure. 7.5 Min fractions were collected. Figure represents the average of 4 individual superfusion experiments. $100 \%$ Values were calculated from the average secretion during fractions 1-4 and were respectively $96 \mathrm{pg}, 204 \mathrm{pg}$, $304 \mathrm{pg}, 196 \mathrm{pg} / 7.5 \mathrm{~min}$ fraction.

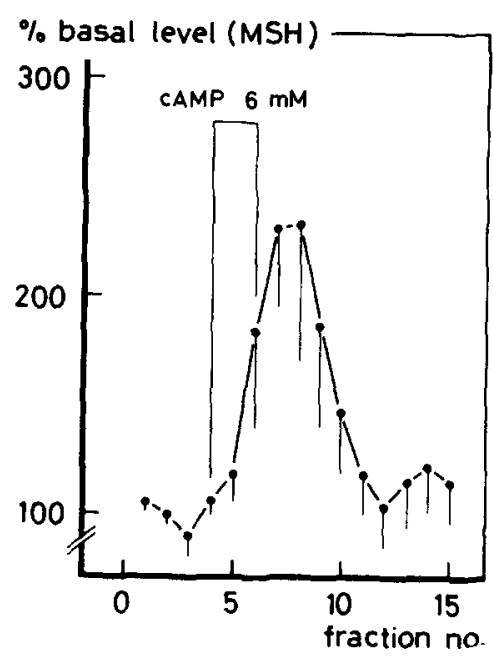

Effects of dopamine, LY171555 and adrenaline on cAMP production and release of $\alpha M S H$

Incubation of intermediate lobe cells in the presence of dopamine $\left(10^{-5} \mathrm{M}\right)$ resulted in a significant decrease of the forskolin stimulated production of cAMP and also the release of MSH from these cells (table 1, fig. 2). Pertussis toxin $(500 \mathrm{ng} / \mathrm{ml})$, an inhibitor of the inhibitory $\mathrm{G}$ protein of the adenylate cyclase system, significantly reduced the dopamine induced inhibition of adenylate cyclase activity and could also completely reverse the dopamine induced inhibition of aMSH release (table 1). The dopamine D'2 receptor agonist $L Y 171555$ $\left(5 \times 10^{-7 M}\right)$, like dopamine, decreased both cAMP production and aMSH release. Adrenaline $\left(10^{-6 M}\right)$ also inhibited both cAMP production and release of $\alpha M S H$.

TABLE I .

Inhibition of cAMP production and MSH release by dopamine, LY171555, and adrenaline in intermediate lobe cells of Xenopus laevis.

\begin{tabular}{|c|c|c|}
\hline & cAMP \% & $\alpha \mathrm{MSH} \%$ \\
\hline Forskolin & 100 & 100 \\
\hline Forskolin + dopamine $\left(10^{-5} \mathrm{M}\right)$ & $42.6 \pm 3.2(n=12)$ & $53.7 \pm 5.5 \quad(n=10)$ \\
\hline $\begin{array}{l}\text { Forskolin + dopamine }\left(10^{-5} \mathrm{M}\right)+ \\
\text { pertussis toxin }(500 \mathrm{ng} / \mathrm{m} 1)\end{array}$ & $65.6 \pm 6.3 \quad(n=5)$ & $98.3 \pm 4.4 \quad(n=4)$ \\
\hline Forskolin + LY171555 (5.10-7M) & $35.3 \pm 4.7 \quad(n=2)$ & $64.4 \pm 5.1 \quad(n=2)$ \\
\hline Forskolin + adrenaline $\left(10^{-6} \mathrm{M}\right)$ & $66.3 \pm 6.7(n=4)$ & $54.1 \pm 3.6 \quad(n=4)$ \\
\hline
\end{tabular}

cAMP production and MSH release were measured after a 45-min incubation of intermediate lobe cells in the presence of forskolin ( $30 \mu \mathrm{M}$ ) and IBMX $\left(10^{-5} \mathrm{M}\right)$. Average absolute levels of control incubations in this medium were resp. 51 pmol cAMP/intermediate lobe equivalent and $3734 \mathrm{pg} \mathrm{MSH/intermediate} \mathrm{lobe} \mathrm{equivalent.}$ cAMP production and MSH release in the presence of dopamine, dopamine + pertussis toxin, LY171555 or adrenaline are expressed as a percentage of their control values. The cAMP values of the experimental groups were all significantly reduced in comparison to the control incubations $(p<0.05)$. Moreover, the incubation with dopamine and pertussis toxin was determined to be significantly different from the value obtained after incubation in dopamine alone (Mann-Whitney U-test). The MSH values obtained after incubation in dopamine, LY171555 and adrenaline were significantly different from their control values. 
Effects of GABAb and GABAa receptor agonists on cAMP production and release of aMSH

Baclofen $\left(1 \sigma^{5} M\right)$, a specific agonist of GABAb receptors induced significant inhibition of cAMP production and aMSH secretion. Isoguvacine $\left(10^{-4} \mathrm{M}\right)$, a specific agonist of GABAa receptors, gave a significant increase in cAMP production. During this incubation MSH release was slightly but not significantly reduced ( $f$ ig. 2 ).

Fig. 2. Effect of dopamine and of GABA agonists on cAMP production and release of MSH in intermediate lobe cells of Xenopus Zaevis. cAMP production and MSH secretion after 45 min of incubation of intermediate lobe cells were measured. All media contained forskolin $(30 \mathrm{\mu M})$ and $\operatorname{IBMX}\left(10^{-4} \mathrm{M}\right)$. Average absolute levels of the control incubation were pmol cAMP/neurointermediate lobe equivalent and $3734 \mathrm{pg}$ $\mathrm{MSH} /$ neurointermediate lobe equivalent. CAMP production and MSH release in the presence of dopamine (DA), baclofien (B) or isoguvacine (I) are expressed as a percentage of their control values. *Significantly different from control $(p<0.5)$.
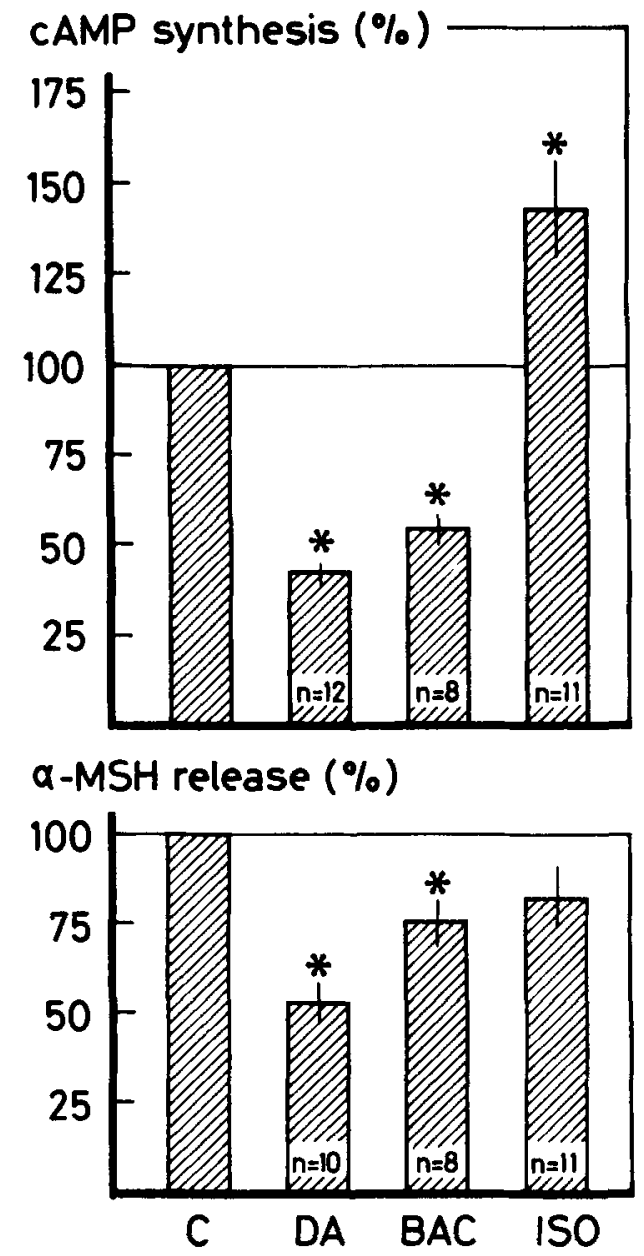

\section{Discussion}

From previous reports, the exact role of adenylate cyclase activity in regulation of MSH secretion from the pars intermedia would seem unclear. Cyclic-AMP analogues have been shown to stimulate $(14,15,18)$, to inhibit (19), or to have no effect on MSH release (23). In a recent study this issue was examined (6). We used neurointermediate lobes in superfusion, which has an advantage over the more commonly used static incubation methods in that the basal secretion provides an internal control. It was shown that pulses of 8 -Br-cAMP stimulate MSH 
release from lobes of white-but not from lobes of black-background adapted animals. The present results show that melanotrope cells, isolated from neurointermediate lobes of black-background adapted animals, are sensitive to cAMP, which caused an enhanced release of MSH. The reason for a different response from whole lobes or isolated cells is not clear. Possibly, the prolonged in vitro inhibition of release due to the isolation of cells in Ca-free medium was sufficient to lower intracellular levels of cAMP, thus propelling the cells towards a physiological condition comparable to that in white-background adapted anima1s.

From the measurement of cAMP production following incubation of isolated melanotropes in dopamine-containing medium we conclude that dopamine induced inhibition of MSH release is intracellularly mediated through inhibition of cAMP production. This conclusion is based on the observations that 1) cAMP is a stimulatory factor for MSH release and 2) dopamine inhibits both cAMP production and release of $\mathrm{MSH}$. In a recent study Loh et al. came to a different conclusion concerning the mechanism of dopamine induced inhibition of MSH secretion (23). This study involved incubation of whole neurointermediate lobes of blackbackground adapted animals. Preincubation of 12-14 days was necessary to allow most of the neural lobe tissue to degenerate, as this latter tissue would mask the CAMP signal from the intermediate lobe. They too found that dopamine, during a 60-min in vitro incubation, inhibits cAMP production but concluded that this neurotransmitter acts via adenylate cyclase not for the inhibition of MSH release but for the direct inhibition of POMC biosynthesis. This conclusion is based firstly, on the finding that cAMP itself had no effect on release of MSH from freshly dissected lobes of black background adapted animals, a phenomenon that we have already commented upon, and secondly, on the finding that a prolonged incubation in the presence of dopamine inhibits POMC synthesis. Concerning this latter observation, in view of the rapid secretory response of the intermediate lobe cells to dopamine, and the prolonged treatment required for this neurotransmitter to inhibit POMC biosynthesis, it is, in our view, not clear to what extent inhibition of POMC synthesis is directly regulated by dopamine.

Dopamine receptors in the mammalian intermediate lobe have been classified as $D_{2}$ dopamine receptors $(24,25,26)$. Mammalian intermediate lobe tissue is in fact often used as a model system for studies on dopamine $D_{2}$ receptors and on the intracellular effects that are generated after stimulation of these receptors $(25,26)$. These mammalian $\mathrm{D}_{2}$ receptors intracellularly evoke inhibition of cAMP production via the inhibitory subunit of the adenylate cyclase system. For the Xenopus laevis neurointermediate lobe it was recently established that the receptors for dopamine show many characteristics of the mammalian $\mathrm{D}_{2}$ receptors but, unlike the latter, they do not respond to the specific $\mathrm{D}_{2}$ antagonist YM09151-2 and are very sensitive to other catecholamines (16). Moreover, it was found that dopamine, the $\mathrm{D}_{2}$ receptor agonist LY171555, and adrenaline, although al1 being blocked by the $\mathrm{D}_{2}$ antagonist sulpiride, did not have an identical profile of antagonists. Therefore, the presence of two catecholaminergic receptors or receptor sites was postulated. The present study shows that activation of Xenopus catecholamine receptors by dopamine, LY171555 or adrenaline evokes a similar intracellular effect, namely inhibition of cAMP production. The apparent inhibitory effect of pertussis toxin $(26,27)$ on dopamine induced inhibition of cAMP production and MSH release would indicate that, as in the mammal, the $N_{i}$ unit of the adenylate cyclase system is involved in the melanotrope cel1 response to dopamine.

Concerning GABAergic mechanisms regulating MSH secretion in Xenopus, we have previously shown that both GABAa and GABAb receptors are present and that the GABAb mechanism is predominant during in vitro treatment with GABA (17). In the pars intermedia of the rat $(28,29)$, the pig (30), and the amphibian Rana ridibunda (31), GABA has been shown to cause a short stimulation in vitro, followed 
by a sustained inhibition. In all cases it is believed that this sustained inhibition is at least partly caused by activation of GABAb receptors (28, 29, $30,31,32$ ). Our present results show that GABAb receptors, 1ike the catecholamine receptors, function through inhibition of adenylate cyclase. While there are reports that GABAb receptors of the central nervous systen of the rat function through inhibition of the adenylate cyclase system $(33,34,35)$, the intracellular mechanism associated with this receptor in inhibiting MSH secretion in either the rat or the amphibian has never been addressed.

The involvement of GABAa receptors in regulating MSH secretion has been reported not only for Xenopus but also for rat $(28,29,32,37)$, pig (30) and Rana ridibunda (31). There appear to be species differences with regard to the tissue response to activation of this receptor type. In all species, the transient stimulation of MSH release functions through a GABAa receptor mechanism. While for the rat and pig there is strong evidence for an important role of GABAb receptors in mediating a sustained inhibition of secretion, for Rana the GABAa receptor is thought to be dominant over the GABAb receptor. In all cases it is believed that stinulation of release is induced through increased membrane permeability to the $\mathrm{C} 1^{-}$ion. In Xenopus we have previously reported a predominant inhibition of MSH secretion through GABA $_{b}$ receptors (17). We suggested that the $\mathrm{Cl}^{-}$electrochemical equilibrium point of the intermediate lobe cells of Xenopus differs from that in the above species and thus opening of $\mathrm{Cl}^{-}$channels in Xenopus would cause hyperpolarization. Our present results concerning activation of GABAa receptors through administration of the specific agonist isoguvacine (37), show a very interesting phenomenon. Isoguvacine is very potent in inhibiting MSH secretion from whole lobes and from melanotrope cells in suspension. We now show that the isoguvacine-induced inhibition of MSH secretion in the presence of forskolin and IBMX is much lower than expected when compared to the results obtained with dopamine and baclofen. Moreover, cAMP production was stimulated by isoguvacine, and thus one would have expected stimulation of MSH release. This discrepancy might indicate that activation of GABAa receptors has a dual effect on the melanotrope cells, namely a stimulatory effect through adenylate cyclase and an inhibitory effect through another intracellular mechanism, possibly the $\mathrm{Cl}^{-}$channel. In our earlier study we showed that GABAa agonists could induce a slight stimulation of MSH secretion at the lowest concentration of their dose-response curve (17), suggesting that in Xenopus intermediate lobes, the stimulatory effect is masked by the predominant inhibitory mechanism. The apparent stimulation at low concentration could be explained when the dual effect is exerted through two sites of the GABAa receptor, or through two different subtypes of the GABAa receptor as has been proposed by Anderson and Mitchel for rat lactotropes $(38,39)$. In our in vitro system adenylate-cyclaselinked stimulation would be revealed only at low concentrations due to a slightly higher sensitivity of this receptor-site or subtype to isoguvacine. The present incubations, however, were performed in a forskolin containing medium. Forskolin is known not only to stimulate the adenylate cyclase but also to potentiate the effect of factors that stimulate the adenylate cyclase activity (40). Potentiation of a GABAa site working through adenylate cyclase might explain the lower inhibition of MSH release by isoguvacine.

In conclusion, the present findings reveal that in the melanotrope cells of the Xenopus pars intermedia at least two distinct intracellular pathways might be involved to generate the final release response. Catecholamines will inhibit the adenylate cyclase through receptors which probably activate the inhibitory subunit. Activation of GABAb receptors will also inhibit intracellular cyclic AMP production. For GABAa receptors we propose that they can induce a dual effect, possibly through two subtypes or sites of this receptor, one of which activates the adenylate cyclase system. In view of this latter finding it should now be established whether the inhibition of $M S H$ release in Xenopus laevis, through activation of GABAa receptors, is caused by a hyperpolarizing shift of the membrane potential through the opening of chloride channels. 


\section{Acknowledgements}

The authors wish to thank Dr P.M.G.M. Willems, Dept. of Biochemistry, Nijmegen, for his advice and gift of cAMP binding protein.

\section{References}

1. J.T. BAGNARA and M.E. HADLEY. The comparative physiology of animal pigmentation. Prentice Hall, Englewood Cliff, New Jersey (1973).

2. H. WARING. Color Change Mechanisms of Cold-Blooded Vertebrates. Academic Press, New York (1963).

3. M. TERLOU, H.J.Th. GOOS and P.G.W.J. VAN OORDT. In: Fortschritte der Zoologie (M. Lindauer, ed.), vol. 22, Verlag, Stuttgart pp 117-134 (1974).

4. A. BOWER, M.E. HADLEY and V. HRUBY. Science 184: 70-72 (1974).

5. M.C. TONON, P. LEROUX, M.E. STOECKEL, S. JEGOU, G. PELLETIER and H. VAUDRY. Endocrinol. 112: 133-141 (1983).

6. B.M.L. VERBURG-VAN KEMENADE, B.G. JENKS, A.P. VAN OVERBEEKE. Gen. Comp. Endocrino1. 63: 471-481 (1986).

7. B.M.L. VERBURG-VAN KEMENADE, M. TAPPAZ, L. PAUT, B.G. JENKS. Endocrinol. 118: 260-267 (1986).

8. M.C. TONON, P. LEROUX, F. LeBoulenger, C. DELARUE, S. JEgOU and H. VAUdRY. Life sciences 26: 869-875 (1980).

9. J.M. DANGER, F. LEBOULENGER, J. GUY, M.C. TONON, M. BENYAMINA, J-C. MARTEL, S. SAINT-PIERRE, G. PELLETIER and H. VAUDRY. Life SCi. 39: 1183-1192 (1986).

10. B.M.L. VERBURG-VAN KEMENADE, B.G JENKS, Th. VISSER, M.C. TONON and H. VAUDRY. Peptides. In press (1987).

11. B.M.L. VERBURG-VAN KEMENADE, B.G. JENKS, J.M. DANGER, H. VAUDRY, G. PELLETIER and S. SAINT-PIERRE. Peptides. In press (1987).

12. B.M.L. VERBURG-VAN KEMENADE, B.G. JENKS and A.G.J. DRIESSEN. Brain. Res. Bull. 17 In press (1986).

13. Y.P. LOH, H. GAINER. J. Gen. Physiol. 70: 37-57 (1977).

14. B.G. JENKS. Front. Hormone Res. 4: $63-6 \overline{5}$ (1977).

15. G.J.M. MARTENS, B.G. JENKS and A.P. VAN OVERBEEKE. Comp. Biochem. Physiol. 69C: $75-82(1981)$.

16. B.M.L. VERBURG-VAN KEMENADE, B.G. JENKS, M.C. TONON and H. VAUDRY. Neuroendocrinol. In press (1986).

17. B.M.L. VERBURG-VAN KEMENADE, B.G. JENKS, F.J.A. LENSSEN, H. VAUDRY. Endocrinol. In press (1986).

18. B.G. JENKS, A.P. VAN OVERBEeke. Comp. Biochem. Physio1. 66C: 71-76 (1980).

19. Y.P. LOH, A. LI, H.A. GRITSCH and R.L. ESKAY. Life Sci. 29: 1599-1605 (1981).

20. H. VAUDRY, C. TONON, M.C. DELARUE, R. VAILLANT and J. KRAICER, Neuroendocrinology 27: 9-24 (1978).

21. H.J.M. KEMPEN, J.J.H.H.M. DE PONT, S.L. BONTING. Biochem. Biophys. Acta 496: 65-76 (1977).

22. B.L. BROWN, J.D.M. ALBANO, R.P. EKINS and A.M. SGHERZI. Biochem. J. 121: $561-563(1971)$.

23. Y.P. LOH, B. MYERS, B. WONG, D.C. PARISH, M. LANG and M.E. GOLDMAN, J. of Biol. Chem. 260: 8956-8963 (1985).

24. T.E. COTE, R.L. ESKAY, E.A. FREY, C.W. GREWE, M. MUNAMURA, J.C. STOOF, K. TSURUTA and J.W. KEBABIAN, Neuroendocrinol. 35: 217-224 (1982).

25. T.E. COTE, E.A. FREY, R.P. SEKURA. J. Biol. Chem. 259: 8693-8698 (1984).

26. T.E. COTE, R. FELDER, J.W. KEBABIAN, R.D. SEKURA, T. REISINE, H-U AFFOLTER, J. Biol. Chem. 261: 4555-4561 (1986).

27. J.D. HILDEBRANDT, R.D. SEKURA, J. CODINA, R. IYENGAR, C.R. MANCLARK, L. BIRNBAUMER. Nature 302: 706-709 (1983).

28. S.A. TOMIKO, P.S. TARASKEVICH, W.W. DOUGLAS, Nature 301: 706-708 (1983). 
29. B.A. DEMENEIX, E. DESAUlles, P. FELTZ, J.P. LOEFfler. Br. J. Pharmacol. 82 : $183-190$ (1984).

30. B.A. DEMENEIX, O. TAlEB, J.Ph. LOEFFleR and P. FELIZ. Neuroscience 15: $1275-1285$ (1986).

31. S. ADJEROUD, M.C. TONON, M. LAMACZ, E. LENEVEU, M.E. STOECKEL, M.L. TAPPAZ, L. CAZIN, J.M. DANGER, C. BERNARD and H. VAUDRY. Brain. Res. Bull. 17. In press (1986).

32. P.S. TARASKEVICH, W.W. DOUGLAS. Neuroscience 14: 301-308 (1985).

33. D.R. HILL, A.C. DOLPHIN. Neuropharmacol. 23: 829-830 (1984).

34. E.W. KARBON! and S.J. ENNA. Mol. Pharmacol. 27: 53-59 (1985).

35. D.R. HILL. Br. J. Pharmacol. 84: 249-257 (1985).

36. P.S. TARASKEVICH and W.W. DOUGLAS. Nature 299: 733-736 (1982).

37. N.G. BOWERY, G.W. PRICE, A.L. HUDSON, D.R. HILL, G.P. WILKIN and M.J. TURNBULL. Neuropharmaco1. 23: 219-231 (1984).

38. R.A. ANDERSON and R. MITCHELL. Proc. of Physiol. Soc. March 1984. J. physiol. 353: $100 \mathrm{p}$ (1984).

39. R.A. ANDERSON and R. MITCHELL. Eur. J. Pharmacol. 124: 1-9 (1986).

40. B. KENNETH, S. DALY and J.W. DALY. Trends in Pharmacol. Sc. 120-123 (1983). 